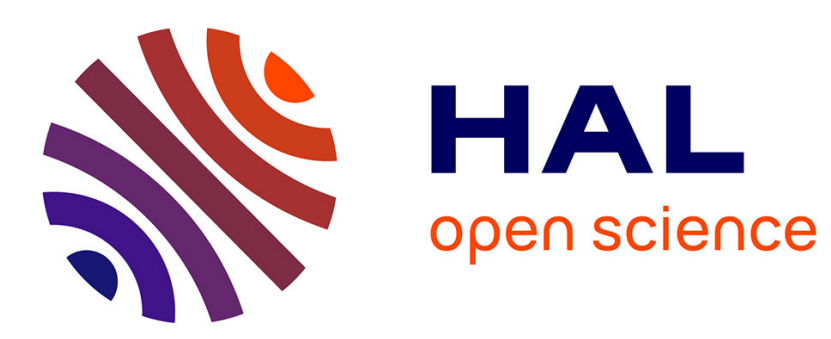

\title{
Investigating the acquisition of the Split-IP parameter and the V2 parameter in second language Afrikaans Simone Conradie
}

\section{To cite this version:}

Simone Conradie. Investigating the acquisition of the Split-IP parameter and the V2 parameter in second language Afrikaans. Second Language Research, 2006, 22 (1), pp.64-94. 10.1191/0267658306sr261oa . hal-00572094

\section{HAL Id: hal-00572094 https://hal.science/hal-00572094}

Submitted on 1 Mar 2011

HAL is a multi-disciplinary open access archive for the deposit and dissemination of scientific research documents, whether they are published or not. The documents may come from teaching and research institutions in France or abroad, or from public or private research centers.
L'archive ouverte pluridisciplinaire HAL, est destinée au dépôt et à la diffusion de documents scientifiques de niveau recherche, publiés ou non, émanant des établissements d'enseignement et de recherche français ou étrangers, des laboratoires publics ou privés. 


\section{Investigating the acquisition of the Split-IP parameter and the V2 parameter in second language Afrikaans}

\section{Simone Conradie Stellenbosch University}

Received February 2003; revised November 2004; accepted December 2004

Researchers who assume that Universal Grammar (UG) plays a role in second language (L2) acquisition are still debating whether L2 learners have access to UG in its entirety (the Full Access hypothesis; e.g. Schwartz and Sprouse, 1994; 1996; White, 1989; 2003) or only to those aspects of UG that are instantiated in their first language (L1) grammar (the No Parameter Resetting hypothesis; e.g. Hawkins and Chan, 1997). The Full Access hypothesis predicts that parameter resetting will be possible where the L1 and L2 differ in parameter values, whereas the No Parameter Resetting hypothesis predicts that parameter resetting will not be possible. These hypotheses are tested in a study examining whether English-speaking learners of Afrikaans can reset the Split-IP parameter (SIP) (Thráinsson, 1996) and the V2 parameter from their L1 ([-SIP], [-V2]) to their L2 $([+\mathrm{SIP}],[+\mathrm{V} 2])$ values. 15 advanced English learners of Afrikaans and 10 native speakers of Afrikaans completed three tasks: a sentence manipulation task, a grammaticality judgement task and a truth-value judgement task. Results suggest that the interlanguage grammars of the L2 learners are [+SIP] and [+V2] (unlike the L1), providing evidence for the Full Access hypothesis.

\section{Introduction}

The unconscious knowledge that many uninstructed second language (L2) learners acquire (i.e. their ultimate attainment) exceeds to a great extent the input to which they are exposed. For this reason, something like the logical problem of first language (L1) acquisition must indeed 
hold for L2 acquisition as well: there is in L2 acquisition, as in L1 acquisition, 'a mismatch between the primary linguistic input and the system actually attained' (White, 1989: 4-5, 37-41). If this is the case, then there is good reason to believe that the L2 learner must have access to at least some aspects of Universal Grammar (UG), i.e. that UG still plays a role in L2 acquisition and that interlanguage (IL) grammars are UG-constrained. The question then remains whether the L2 learner has access to UG in its entirety (the Full Access hypothesis; see Schwartz and Sprouse, 1994; 1996; Vainikka and Young-Scholten, 1994; 1996; White, 1989; 2003) or only to those aspects of UG instantiated in his/her L1 grammar (the No Parameter Resetting hypothesis; see Clahsen and Muysken, 1989; Tsimpli and Smith, 1991; Hawkins et al., 1993; Smith and Tsimpli, 1995; Hawkins and Chan, 1997). These two hypotheses make different predictions with respect to the possibility of parameter resetting in L2 acquisition in situations where the value of a certain parameter differs for the learner's L1 and the target L2: the No Parameter Resetting hypothesis predicts that parameter resetting should not be possible, whereas the Full Access hypothesis predicts that parameter resetting should be possible if the necessary positive evidence is available in the input. Given these differing predictions, it is necessary to study the acquisition of parameters whose values differ for the learner's L1 and the target L2 in order to gain insight into the role of UG in L2 acquisition. One such situation is found in the L2 acquisition of the Split-IP parameter (SIP) (Thráinsson, 1996) and the V2 parameter in Afrikaans by native speakers of English. Consequently, it is of interest to investigate whether English-speaking learners of Afrikaans reset these parameters. Following the Full Access hypothesis, I predict that such learners will indeed be able to reset the parameters. The study reported in this article was set up to test this prediction.

The article is organized as follows: Section II provides a discussion of the SIP and the V2 parameter, and shows that English is a non-V2 [-SIP] language, whereas Afrikaans is a V2 [+SIP] language. Section III provides an overview of the relevant current hypotheses in L2 acquisition theory. In Section IV, a report is given of a study on the L2 acquisition of the SIP and the V2 parameter by English-speaking learners of Afrikaans, and Section $\mathrm{V}$ provides a brief discussion of some issues raised by the study. 


\section{Two parameters: the SIP and the V2 parameter}

\section{The split-IP parameter (SIP)}

Pursuing the idea that languages might differ as to which functional categories they have in their IP-complex ${ }^{1}$ (see, e.g. Iatridou, 1990), Thráinsson (1996: 262) proposed the Split-IP parameter (SIP), according to which [+SIP] languages have separate Agr and T projections, whereas [-SIP] languages have an unsplit, pre-Pollockian IP.

Although recent work in the Minimalist Program has abandoned independent Agr heads (for discussion, see Chomsky, 1995), Bobaljik and Thráinsson (1998) show how the existence of something like the SIP can be used to account for some cross-linguistic variation in morphology and syntax. Since [+SIP] languages by definition have more projections in their IP-complex than $[ \pm=$ SIP] languages, it follows that $[+\mathrm{SIP}]$ languages have additional specifier positions that are not available in $[ \pm=\mathrm{SIP}]$ languages. For this reason, constructions that make use of these additional specifier positions are only allowed in [+SIP] languages. Two such constructions are transitive expletive constructions (TECs) and full-NP Object Shift constructions (OSCs).

TECs are constructions that contain both a transitive verb and an expletive. Although $[ \pm=\mathrm{SIP}]$ languages such as English allow constructions containing an unaccusative (hence, intransitive) verb and an expletive (1a), they do not allow TECs (1b). [+SIP] languages such as Icelandic, on the other hand, do allow TECs (2). ${ }^{2}$

1) a. There appeared a train in the distance.

b. * There has a cat eaten the mice.

2)

$\begin{array}{lllll}\text { pað hefur einhver köttur étið } & \begin{array}{l}\text { mýsnar. } \\ \text { expletive has some }\end{array} \\ \text { 'A cat has eaten the mice.' } & & \text { eaten } & \text { mice-the }\end{array}$

The assumption here is that the subject NP of a transitive verb is not allowed to remain VP-internal (see, for example, Chomsky, 1995; Bobaljik and Jonas, 1996; Alexiadou and Anagnostopoulou, 1997).

\footnotetext{
${ }^{1}$ The term 'IP-complex' is taken from Bobaljik and Thráinsson (1998: 38) and refers to 'the collection of inflectional heads and their phrases that together make up the articulated IP'.

${ }^{2}$ The examples from Icelandic are taken from Bobaljik and Thráinsson (1998) and are included here because this is the language used to represent [+SIP] languages in that article (English is used to represent [-SIP] languages). In each case, these examples are followed by examples from Afrikaans, which I argue indicate that this language is, like Icelandic, $[+\mathrm{SIP}]$.
} 
This means that, in [-SIP] languages such as English, the subject NP of a transitive verb must move into Spec,IP, as there is no other specifier position higher than Spec,VP; but this is exactly the position that an expletive would occupy. Thus, in TECs in [-SIP] languages, two elements (the expletive and the subject NP) would have to occupy a single position (Spec,IP), which is not possible. This explains why TECs are ungrammatical in [-SIP] languages: these languages simply do not have the phrase structure to accommodate TECs. ${ }^{3}$ In [+SIP] languages, on the other hand, there is more than one specifier position above Spec,VP so that even if an expletive occupies one of these specifier positions, the subject can still move out of Spec,VP and into another specifier position in the IP-complex. For this reason, TECs are only allowed in $[+\mathrm{SIP}]$ languages.

Although some researchers claim that Afrikaans does not allow TECs (Bobaljik and Jonas, 1996, following Donaldson, 1993) and that constructions such as that in (3) must involve locative daar 'there' instead of expletive daar, the examples in (4) to (6) show that Afrikaans does indeed allow true TECs.

3) Daar het 'n kat die muise geëet. there has a cat the mice eaten

'A cat ate the mice.'

4) Daar het iemand hier vuur gemaak. there has someone here fire made 'Someone made a fire here.'

5) Gister het daar iemand daar 'n vuur gemaak. yesterday has there someone there a fire made 'Yesterday someone made a fire there.'

6) a. Daar het 'n agent vir Jan gebel oor sy huis. there has an agent for Jan phoned about his house 'An agent phoned Jan about his house.'

b. \# Regtig? Waar?

'Really? Where?'

If daar were to be interpreted as a locative in (4), the sentence would be ill- formed (as the two adverbs, daar and hier, are contradictory). 
The fact that this sentence is completely well- formed, indicates that it is an example of a true TEC. Furthermore, (5) would be ill- formed if both of the instances of daar were to be interpreted as locatives; as the sentence is completely well formed, this entails that one of the instances of daar must be an expletive. Finally, if there is an implied location that daar picks out in A's utterance in (6), then B's question should be felicitous, but it is not. Therefore, daar in A's utterance cannot be locative and must be an expletive, which means that this utterance is another instance of a true TEC.

Finally, note that locative daar and expletive daar also differ in their distribution. The sentences in (7) show that a locative adverb (here, hier 'here') can occur between the subject (here, iemand 'someone') and the object (here, 'n vuur 'a fire'), but cannot occur in the position preceding both the subject and the object. This is why the sentence in (8) is only acceptable when daar is read as an expletive; the placement of daar in the position preceding both the subject and the object excludes a locative reading. If one wants to read daar as a locative in this sentence, it must be placed as in (9), between the subject and the object. In this position, it can only be read as a locative, which is indicated by the meaning of the sentence: whereas (8) means 'Yesterday someone made a fire', (9) means 'Yesterday someone made a fire there'. Given the data in (4) to (9), it should be clear that Afrikaans does indeed allow true TECs.

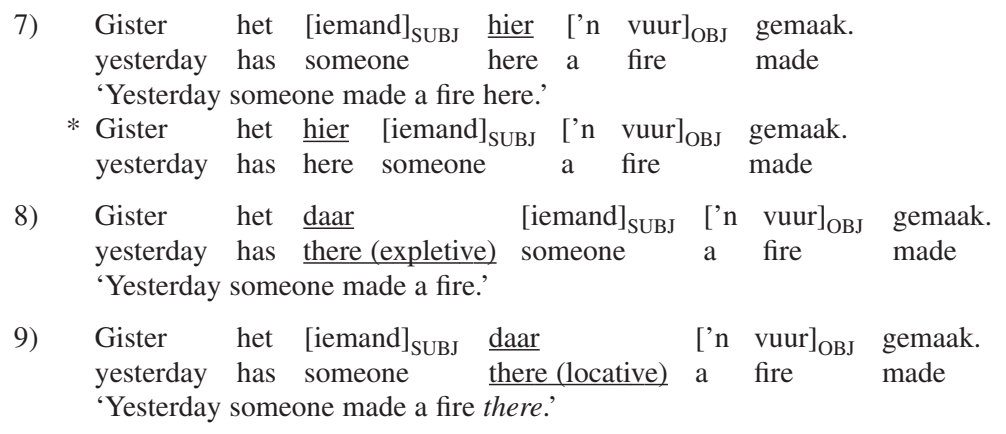

OSCs are constructions in which a non-pronominal direct object NP has been moved leftward over some element that is taken to mark the left edge of VP: a sentence-medial adverb, floating quantifier or negative element (for the sake of convenience, I refer to these as 
'left-edge markers') (Bobalijk and Thráinsson, 1998: 53). In the examples in (10b) and (11b), the direct object NP three books / prjár boekur has been moved from its VP-internal position over the negative element not / ekki. As can be seen from these examples, such object shift is allowed in [+SIP] languages such as Icelandic (11b) but not in [-SIP] languages such as English (10b).

10) a. I did not read three books.

b. * I did three books not read.

$\begin{array}{rllll}\text { 11) a. } & \text { Ég las ekki } & \text { prjár } & \text { bækur. } \\ & \text { I read not three } & \text { books } \\ \text { b. } & \text { Ég las prjár bækur ekki. } \\ & \text { I read three books not } \\ & \text { 'I didn't read three books.' }\end{array}$

It is commonly assumed that the landing site of object shift is the specifier of a projection higher than vP but lower than T. (In earlier work this projection was assumed to be AgrOP.) [+SIP] languages have such a projection but $[-\mathrm{SIP}]$ languages do not. Thus, only $[+\mathrm{SIP}]$ languages have the required phrase structure to accommodate OSCs.

12) a. Ek het nie drie boeke gelees nie.

I have not three books read final-NEG

b. Ek het drie boeke nie gelees nie.

I have three books not read final-NEG

'I didn't read three books.'

As is illustrated by the example in (12b), object movement can be found in Afrikaans, but there is a question about whether it involves OS or Scrambling. (The same question is being debated with respect to object movement constructions in German and Dutch.) OS is the A-movement of the direct object NP into the projection intermediate between $\mathrm{T}$ and $\mathrm{vP}$, whereas Scrambling is the $\mathrm{A}^{\prime}$-movement of the direct object NP to an adjoined position (such as the position adjoined to IP). Therefore, if Afrikaans object movement constructions are instances of OS, then they provide evidence for a $[+\mathrm{SIP}]$ setting in this language. If, on the other hand, these constructions are instances of Scrambling, then they are irrelevant to the setting of the SIP: that a direct object-NP can adjoin to, for example, IP does not tell us anything about the internal structure of the IP-complex.

Diesing (1997) compared the 'reordering possibilities' of Yiddish to those of some West Germanic and Scandinavian languages and 
concluded that object movement constructions in Yiddish and German are instances of Scrambling, whereas object movement constructions in Dutch and Icelandic are instances of OS. Her conclusion was based primarily on the following differences between object movement constructions in these languages:

1) the direct object and the indirect object cannot both move out of VP in double-object constructions in Dutch and Icelandic, but they may do so in German and Yiddish; and

2) the direct object cannot move over the subject in Dutch and Icelandic, but it may do so in German and Yiddish.

The reader is referred to Diesing's (1997) article for an account of the relevance of these two properties. Suffice it to say that they are linked to Rizzi's (1990) notion of relativized minimality and that, whereas the possibility of the properties mentioned in (1) and (2) (as in the case of German and Yiddish) indicates that the leftward movement of the direct object is an A'-movement (hence, Scrambling), the impossibility of these properties (as in the case of Dutch and Icelandic) indicates that the leftward movement of the direct object is an A-movement (hence, OS). Turning to Afrikaans, the examples in (13) and (14) show that this language patterns together with Dutch and Icelandic with respect to the properties in (1) and (2). ${ }^{4}$

13) a. Ek het nie vir Marie die boeke geleen nie.

I have not for Mary the books lend final-NEG

'I did not lend Mary the books.'

b. * Ek het die boeke vir Marie nie geleen nie.

I have the books for Mary not lend final-NEG

14) a. Gister het Jan die boeke nie gelees nie.

yesterday has John the books not read final- NEG

'Yesterday John did not read the books.'

b. * Gister het die boeke Jan nie gelees nie.

yesterday has the books John not read final-NEG

The sentences in (13) show that Afrikaans does not allow the direct object and the indirect object to both move out of VP in double-object constructions, and the sentences in (14) show that Afrikaans does

${ }^{4}$ The sentences in (13) and (14) are the Afrikaans translations of the Dutch and Icelandic sentences that Diesing (1997) used to diagnose object movement in these two languages with respect to the properties in (1) and (2). 
not allow the direct object to move over the subject. Consequently, according to these two diagnostics, Afrikaans object movement involves OS, and not Scrambling.

Bobaljik (1995: 123-43) also provides arguments for the claim that the leftward movement of the direct object across left-edge markers in Afrikaans involves 'A-movement, i.e. shift to Spec,AgrOP, as opposed to clause-internal adjunction or A'-movement'. In fact, Bobaljik (1995: 124, footnote 6) argues that OS is attested in all Germanic languages, except English (including Afrikaans, German and Dutch). His strongest argument involves floating quantifiers: A-movement licenses floating quantifiers while $\mathrm{A}^{\prime}$-movement does not, and since the object movements in Icelandic, German and Dutch license floating quantifiers, they are all instances of A-movement (Bobaljik, 1995: 128-35). Bobaljik (1995: 135) concludes that 'the short leftwards movement of objects even in SOV Germanic languages [such as Afrikaans; SC] is object shift, that is, that it involves an A-movement operation.'

Diesing (1997: 407) admits that, although Yiddish and German Scrambling exhibits A'-movement properties, it also exhibits some A-movement properties. Furthermore, as she notes in a footnote, 'the mixture of A and $\mathrm{A}^{\prime}$ properties ... may well result from two stages of movement, an initial A-movement stage (perhaps movement to the specifier of some Agr head), followed by an A' stage' (Diesing, 1997: 407, footnote 23). Mahajan (1990) provides arguments for the idea that there are no mixed $\mathrm{A}-\mathrm{A}^{\prime}$-positions and no mixed $\mathrm{A}-\mathrm{A}^{\prime}$-movements and that, therefore, movements that seem to be mixed must consist of an A-movement followed by an $\mathrm{A}^{\prime}$-movement. If this is true, then the question of whether Afrikaans object movement is OS or Scrambling becomes irrelevant, as even $\mathrm{A}^{\prime}$-Scrambling would include a prior A-movement of the object into Spec, AgrOP, and would thus require a split IP. Nevertheless, the arguments made on the basis of Diesing's and Bobaljik's diagnostics all point to Afrikaans object movement involving A-movement-OS. Consequently, I believe that it is safe to conclude that Afrikaans object movement involves OS and that object movement constructions in this language do indeed indicate that it is a $[+\mathrm{SIP}]$ language. ${ }^{5}$ 
Two other properties that Bobaljik and Thráinsson link to the [+SIP] setting are:

1) the co-occurrence of an agreement marker and a tense marker on a single verb form; and

2) verb raising in non- $\mathrm{V} 2$ environments (i.e. verb raising to a head position in the IP-complex).

However, these properties are not discussed in this article as they are irrelevant in the case of the L2 under investigation, namely Afrikaans, because this language (1) does not have any overt agreement markers and (2) is an SOV V2 language, which means that verb raising in non-V2 environments would not be visible (since all projections below $\mathrm{CP}$ are believed to be head-final in Afrikaans: the verb will be in clausefinal position regardless of whether it has remained in VP or moved to another head-final projection). Consequently, the only two SIP properties that are discussed in this article are TECs and OSCs.

To summarize, in this section it was argued that Afrikaans is a [+SIP] language that allows both TECs and OSCs, whereas English is a $[-\mathrm{SIP}]$ language that allows neither TECs nor OSCs.

\section{The V2 parameter}

As was mentioned at the end of the previous section, verb raising in non-V2 environments is associated with the setting of the SIP. Verb raising in V2 environments, on the other hand, is associated with the setting of the V2 parameter. ${ }^{6}$ The setting of this parameter can be linked to the presence/absence of a certain feature in C. This V2-feature is present in $\mathrm{V} 2$ languages, forcing the verb to raise into $\mathrm{C}$, and absent in non-V2 languages, forcing the verb to remain in VP. ${ }^{7}$

The consequences of the setting of the V2 parameter are visible in nonsubject initial main clauses (NSIMCs). In V2 languages, such as Afrikaans, a sentence-initial adverbial phrase or topicalized object is in

${ }^{6}$ It is commonly assumed that in V2 environments the head C (the head of the complementizer phrase) has some features that require the verb to raise into $\mathrm{C}$ and an XP (either the subject or a topicalized element) to raise into Spec,CP.

${ }^{7}$ This claim pertains only to non-V2 languages that are [-SIP], such as English. I do not deal with non-V2 [+SIP] languages (such as French) in this article. 
Spec,CP and is immediately followed by the verb (which is in second position, in C). In non-V2 languages, such as English, a sentence-initial adverbial phrase or topicalized object is adjoined to IP and is immediately followed by the subject (in Spec, IP), and the verb appears in third position (inside VP). Consequently, V2 languages, such as Afrikaans, have V2-NSIMCs (i.e. NSIMCs in which the verb appears in second position; see (15)), whereas non-V2 languages, such as English, have V3-NSIMCs (i.e. NSIMCs in which the verb appears in third position; see (16)). ${ }^{8}$

15) Die jakkals het Olaf met hierdie geweer geskiet.

the fox has Olaf with this gun shot

'The fox Olaf shot with this gun.'

* Die jakkals Olaf het met hierdie geweer geskiet.

16) The fox Olaf shot with this shotgun.

* The fox shot Olaf with this shotgun. (meaning 'The fox was shot by Olaf with this shotgun.')

Finally, note that, as implied in footnote 6, I follow Bobaljik and Thráinsson in assuming that subject-initial main clauses (SIMCs), like NSIMCs, are CPs and, therefore, that SIMCs are V2 environments in V2 languages such as Afrikaans (see also, for example, Schwartz and Vikner, 1996). This means that the position of the verb in SIMCs is also linked to the setting of the V2 parameter in Afrikaans: because this language is [+V2], the verb raises out of VP and into $\mathrm{C}$ in SIMCs (as in NSIMCs) and, for this reason, precedes left-edge markers (see (17)). In English, on the other hand, the verb remains in VP in SIMCs (as in NSIMCs) and, for this reason, follows left-edge markers (see (18)).

17) Helgi lees dikwels boeke.

Helgi reads often books

'Helgi often reads books.'

* Helgi dikwels lees boeke.

18) Helgi often reads books.

* Helgi reads often books.

To summarize, the data provided in Section II provide evidence that English is a non-V2 [-SIP] language and Afrikaans is a V2 [+SIP] language.

${ }^{8}$ In this article, I regard V2-NSIMCs as indicative of a [+ V2] setting and V3-NSIMCs as indicative of a [-V2] setting, and I ignore the fact that English, and other non-V2 languages, also allow V4-NSIMCs such as Yesterday, the fox Olaf shot with this shotgun, as noted by one reviewer. The important point here is that V2 languages do not allow V3-NSIMCs, and non-V2 languages do not allow V2-NSIMCs. 


\section{The possibility of parameter resetting in L2 acquisition: current hypotheses and previous research}

\section{The No Parameter Resetting Hypothesis}

Proponents of the No Parameter Resetting hypothesis include Smith and Tsimpli (1995) (see also Tsimpli and Smith, 1991), Hawkins and Chan (1997) (see also Hawkins et al., 1993) and Clahsen and Muysken (1989). To account for (1) some fundamental differences between the L1 and L2 acquisition of German verb placement (Clahsen and Muysken, 1986) and (2) the convincing results of some L2 acquisition studies that suggest that universal UG principles are available to adult L2 learners (Clahsen and Muysken, 1989), Clahsen and Muysken (1989: 23, 26) propose that adult L2 learners have indirect access to the universal principles of UG via their L1 grammar, but that they no longer have access to the 'open parameters' of UG. Consequently, where the L1 and L2 grammar differ from each other, the L2 learner will not be able to (re-)set the relevant parameters and will instead have to accommodate the relevant L2 data with the aid of general (non-UG) learning strategies (Clahsen and Muysken, 1989: 2). Hawkins and Chan (1997) attempt to provide a syntactic characterization of this partial availability of UG. Following proposals made by Smith and Tsimpli (1995), they propose the Failed Functional Features hypothesis, which states that all and only the features of the functional categories (which determine parametric differences between languages) are subject to a critical period. After this critical period, L2 learners will have access only to the principles of UG and to the features instantiated in their L1 grammar. This means that only the parameters and parameter values instantiated in the learner's L1 grammar are available to the L2 learner and that parameter resetting is not possible. Hawkins and Chan (1997) report the results of a study in which Chinese-speaking learners of English were unable to acquire the [wh]-feature of English C (a feature which is absent from their L1 grammar). Similarly, Hawkins et al. (1993) claim that the intermediate English-speaking learners of French in their study were unable to reset the parameter that determines the position of the verb in non-V2 environments. (According to Pollock (1989), this is the [ \pm opacity] of Agr parameter. I refer to all non-SIP versions of this parameter as 'the verb-placement parameter'.) The results 
of both of these studies are thus consistent with the No Parameter Resetting hypothesis.

\section{The Full Access hypothesis}

Proponents of the Full Access hypothesis (Schwartz and Sprouse, 1994; 1996; Vainikka and Young-Scholten, 1994; 1996; White, 1989; 2003) claim that the L2 learner still has full access to UG. According to this hypothesis, restructuring of the IL grammar, including parameter resetting from the L1 parameter value to the L2 parameter value (or to a value instantiated in some other natural language), is possible in principle, on the basis of L2 input and with the aid of UG. Du Plessis et al. (1987) investigate the L2 acquisition of the V2 parameter. They reanalyse Clahsen and Muysken's (1986) data and provide additional data from (1) English and French learners of German and (2) English learners of Afrikaans. They show how all of these data can be accounted for in terms of three interacting parameters - the headedness parameter, the proper government parameter and Travis's (1986) adjunction parameter - if one assumes that the learners start out with the L1 values of the parameters and gradually reset the parameters, either to the correct target L2 value or to a value instantiated in another natural language. Yuan (2001) reports the results of a study in which it appeared that English, French and German learners of Chinese could set the verbplacement parameter in their IL grammars to the value that was correct for the target L2 (Chinese) and, most importantly, a value different from that in the French and German learners' L1 grammars. Similarly, Ayoun (1999) claims that the English learners of French in her study were in the process of resetting the verb-placement parameter. These three studies provide evidence in favour of the Full Access hypothesis.

\section{The SIP and the V2 parameter}

The study reported in the next section investigates whether Englishspeaking learners of Afrikaans can reset the SIP and the V2 parameter from their L1 to their L2 values. A number of recent studies (see, for example, White 1996; Ayoun, 1999; Duffield and White, 1999; Yuan, 2001) show that L2 learners are able to reset feature strength and to acquire features or functional categories that are not instantiated in their 
L1s, which is what English learners of Afrikaans would have to do in order to reset the SIP and the V2 parameter. Some of the studies investigating the L2 acquisition of the V2 parameter and the verbplacement parameter were mentioned above (Clahsen and Muysken, 1986; 1989; Du Plessis et al., 1987; Hawkins et al., 1993; Ayoun, 1999; Yuan, 2001). To my knowledge, no research has been done specifically on the L1 or L2 acquisition of the SIP.

\section{The study}

\section{Hypothesis and predictions}

Following the Full Access hypothesis, I predict that English-speaking learners of Afrikaans will be able to reset both the SIP and the V2 parameter from their L1 to their L2 values (though not necessarily at the same time). If the L2 learners have reset both of the parameters, then they should produce and/or accept as grammatical (1) SIMCs in which the verb precedes (instead of follows) a left-edge marker, (2) V2NSIMCs (instead of V3-NSIMCs), (3) OSCs and (4) TECs.

\section{Subjects}

There were three groups of subjects in this study: 15 advanced L2 learners of Afrikaans whose L1 is English (the L2ers) (aged between 19 and 21 years), 10 native speakers of Afrikaans (the Afrikaans Controls) (aged between 19 and 24 years) and 10 native speakers of South African English (the English Controls) (aged between 19 and 24 years). All of the subjects were students in the English Department at Stellenbosch University (in South Africa) at the time of testing.

The L2ers were all native speakers of English, who (1) had spoken only English at home while growing up, (2) had attended Englishmedium primary and high schools and (3) described their proficiency in Afrikaans as advanced. ${ }^{9}$ Because all of the L2ers were born and raised in South Africa, they were exposed to Afrikaans from birth, but they all 
noted that they had only actually started using Afrikaans at school (somewhere between the ages of 7 and 9) when they had started receiving some basic instruction in Afrikaans as a second language.

The L2ers were used to test the main hypothesis and its predictions and the Afrikaans Controls were used to test the validity of the tasks and to serve as a comparison for the L2ers. The English Controls were tested to make sure that South African English is indeed, like Standard English, a non-V2 [-SIP] language.

\section{Tasks}

The L2ers and the Afrikaans Controls completed three tasks (in this order): a sentence manipulation task, a grammaticality judgement task, and a short truth-value judgement task (see sections a, b and c below). The English Controls completed only a grammaticality judgement task (see section d). ${ }^{10}$ The instructions for each task were provided in the subject's L1 (Afrikaans for the Afrikaans Controls, and English for the English Controls and the L2ers).

a Sentence manipulation task (L2ers and Afrikaans Controls): The sentence manipulation task was based on that in White (1991). The subject was asked to rearrange sets of randomly shuffled Afrikaans word cards in order to form as many acceptable sentences as possible. There were 18 sets of word cards that the subject had to manipulate: 6 SIMC sets $(3 \times$ adverb and $3 \times$ negative element), 6 NSIMC sets $(3 \times$ sentence-initial adverb and $3 \times$ topicalized object) and 6 OSC sets $(3 \times$ adverb and $3 \times$ negative element). An illustrative example is given in (19). In this example, the 'cards' (indicated by square brackets) are arranged in such a way that they form the targeted sentence. ${ }^{11}$

\footnotetext{
${ }^{10}$ To control for ordering effects, there were two versions of each task. In each case, version 2 had the reverse order of version 1 . Subjects were randomly assigned to a version of each task.

${ }^{11}$ Note that it is possible to form many grammatical and ungrammatical sentences other than the targeted sentence with each set of word cards. Each (grammatical and ungrammatical) sentence formed by the subjects that falls into any category targeted by the sentence manipulation task (even if the sentence itself was not targeted by the task) is counted and is included in the numbers in Table 2 (the results of the sentence manipulation task). This should not be regarded as problematic since the idea of this task is simply to provide the subjects with the building blocks needed to form constructions that could indicate the settings of the SIP and the V2 parameter in the subjects' IL grammars. If, for example, a subject forms a *V3-NSIMC, this is counted as a *V3-NSIMC, and it is irrelevant which actual set of word cards was used to form this sentence.
} 
19) [die supermodel] [wen] [dikwels] [skoonheidskompetisies]. the supermodel wins often beauty.pageants 'The supermodel often wins beauty pageants.'

(SIMC-adv)

b Grammaticality judgement task (L2ers and Afrikaans Controls): The grammaticality judgement task was based on the written preference task in White (1991). The subject was presented with 50 pairs of Afrikaans sentences and asked to circle or underline one of the options below each pair. An example of a test pair is given in (20). (English glosses and the correct answer are included here.) (The sentence types tested on this task are set out at the top of Table 3 below.)

$\begin{array}{rllll}\text { 20) a. Dirk kyk soms sport } & \text { op televisie. } \\ \text { Dirk watches } & \text { sometimes } & \text { sports } & \text { on television } \\ \text { b. Dirk soms kyk } & \text { sport } & \text { op } & \text { televisie. } \\ \text { Dirk } & \text { sometimes } & \text { watches } & \text { sports } & \text { on television } \\ \text { 'Dirk sometimes watches sports on television.' }\end{array}$

(SIMC-adv)

Only (a) is possible Only (b) is possible Both possible Both impossible Don't know

c Truth-value judgement task (L2ers and Afrikaans Controls): The truth-value judgement task was designed to determine whether the L2ers had knowledge of one of the semantic effects of OS in Afrikaans, as OS does not occur in their L1 (English). At issue is the following: In Afrikaans, if a direct object NP is modified by a number (e.g. drie boeke 'three books') and this NP remains VP-internal in a negative clause, then the negative element takes scope over the direct object and the number modifying it. However, if this NP is shifted out of the VP and across the negative element, then the direct object and the number modifying it take scope over the negative element. This results in a clear interpretive difference, which is illustrated by the sentences in (21) and (22).

21) Sven het nie drie boeke gelees nie. (No-OS: NEG $>$ \#DO)

Sven has not three books read final-NEG

'It is not true that Sven has read three books.'

22) Sven het drie boeke nie gelees nie. (OS: \#DO > neg)

Sven has three books not read final-NEG

'There are three books that Sven hasn't read.' 
Keeping the sentences in (21) and (22) in mind, consider the context in (23):

23) Sven is taking a course in English literature at the university. They have to do a lot of reading for this course and Sven has trouble keeping up because he cannot read very fast. For this week's class he had to read 4 books but he only read 2. Fortunately, the class got cancelled and now Sven has another weekend to try and get the reading done.

Given the context in (23), the no-OS sentence in (21) is true (since Sven has only read two books, not three), while the OS sentence in (22) is false (since there are only two books that Sven has not read, not three). In the truth-value judgement task, the subjects were presented with contexts such as that in (23) (provided in their L1), each followed by a morphosyntactically well-formed Afrikaans sentence (either a no-OS sentence or an OS-sentence). Subjects were asked to judge each Afrikaans sentence as true or false, given the preceding context. (This task is based on that in Dekydtspotter et al., 1999.) Subjects had to judge 6 test items and 4 distracters. The 6 test items all involved utterances such as those in (21) and (22), with a transitive verb, the negative element nie and a direct object NP modified by a number. In the 3 no-OS items, the utterance was true, and in the 3 OS items, the utterance was false. ${ }^{12}$

d Grammaticality judgement task (English Controls): The English Controls were asked to judge the acceptability of English sentence pairs, which were, as far as possible, close translations of the sentences used in the Afrikaans grammaticality judgement task. Recall that the reason for including this task was to show that South African English, like Standard English, is a non-V2 [-SIP] language.

\section{Results}

a English Controls: The English Controls' accuracy (in percentage) in judging the various sentence types on the grammaticality judgement task is given in Table 1 . These scores might seem a little

\footnotetext{
${ }^{12}$ The reason for this distribution is to avoid Type I errors. Crain and Thornton (1998) argue that, in truth-value judgement tasks testing whether a certain constraint is present, the meaning ruled out by the adult L1 grammar should evoke a 'yes'/true' response, and the meaning allowed by the adult L1 grammar should evoke a 'no'/false' response.
} 
80 The Split-IP parameter and the V2 parameter in L2 Afrikaans

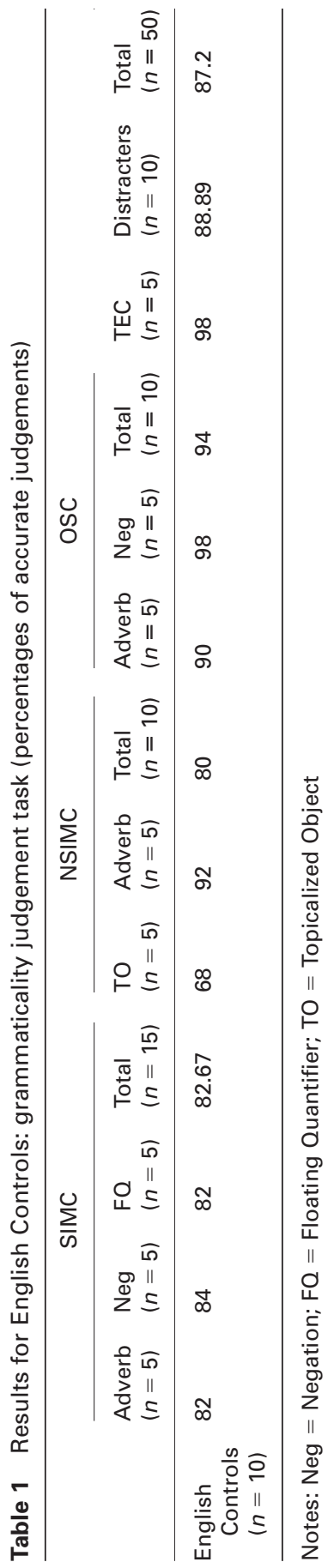


low for a control group, but this may primarily be due to one particular instruction on the grammaticality judgement task. Recall that subjects were instructed to circle one option beneath each sentence pair in this task: 'only (a) is possible', 'only (b) is possible', 'both possible', 'both impossible' or 'don't know'. The instruction as to the 'both possible' option reads as follows: 'If you think that both sentences are possible, circle 'Both possible'. (Circle the 'Both possible' option when you think that both sentences are possible, even when you prefer one over the other.)'. The instruction in brackets was added to ensure that subjects would not circle 'only (a) is possible' or 'only (b) is possible' if they found both sentences in a pair possible but preferred one over the other for idiosyncratic reasons. However, this instruction seems to have led to some of the subjects tolerating ungrammatical sentences that they would otherwise have judged as unacceptable. I base this claim on (1) comments that were made by the subjects after they had completed the task and (2) an error analysis (see directly below).

Of the 400 pairs (i.e. 10 subjects $\times 40$ non-distracter pairs) judged by the English Controls (as a group), a total of 53 were judged incorrectly. Of these 53 pairs, 31 were judged as 'both possible'. As was explained above, these errors are believed to be due to the additional 'both possible' instruction. Another 16 pairs were judged as 'both impossible'. 13 of these 16 pairs were NSIMCs involving a topicalized object. This simply suggests that the English Controls dislike topicalized objects, which would explain their very low accuracy score on NSIMCs involving a topicalized object (68\%). The remaining 6 pairs that were judged incorrectly were judged as either 'only (a) is possible' or 'only (b) is possible'. Thus, the English Controls preferred an ungrammatical sentence to a grammatical sentence for only 6 of the 400 pairs (a mere 1.5\%). Finally, the English Controls correctly rejected TECs as unacceptable $98 \%$ of the time and correctly rejected OSCs as unacceptable $94 \%$ of the time. In light of this breakdown of the English Controls' errors, it is safe to say that South African English, like Standard English, is indeed a non-V2 [-SIP] language.

$b$ Afrikaans Controls and L2ers: The results of the sentence manipulation task are given in Table 2. The numbers in the TOTAL-row 
Table 2 Results for Afrikaans Controls (ACs) and L2ers: sentence manipulation task (number of sentences built for each sentence type)

\begin{tabular}{|c|c|c|c|c|c|c|c|}
\hline & \multicolumn{2}{|c|}{ SIMC-A(dv) } & \multicolumn{2}{|c|}{ SIMC-N(eg) } & \multicolumn{2}{|r|}{ NSIMC } & \multirow[b]{2}{*}{ OSC } \\
\hline & SVAO & *SAVO & SVNO & *SNVO & V2-NSIMC & *V3-NSIMC & \\
\hline \multicolumn{8}{|l|}{$\operatorname{ACs}(n=10)$} \\
\hline Total & 31.0 & 0 & 30 & 0 & 155.0 & 0 & 37.0 \\
\hline Mean & 3.1 & 0 & 3 & 0 & 15.5 & 0 & 3.7 \\
\hline \multicolumn{8}{|l|}{ L2ers $(n=15)$} \\
\hline Total & 44.0 & 0 & 45 & 0 & 210 & 1.00 & 54.0 \\
\hline Mean & 2.93 & 0 & 3 & 0 & 14 & 0.07 & 3.6 \\
\hline
\end{tabular}

represent the total number of sentences formed for each sentence type by the Afrikaans Controls (ACs) as a group and by the L2ers as a group. ${ }^{13}$

The Afrikaans Controls did not form any ungrammatical sentences in this task. One L2er formed a single ungrammatical sentence (a V3NSIMC), but since this is a single instance and represents $0.47 \%$ of the NSIMCs formed by the L2ers, it can be regarded as a performance error and ignored. Furthermore, by comparing the means of the L2ers to those of the Afrikaans Controls, it should be clear that the L2ers performed exactly like native speakers on all of the sentence types, suggesting that, in their IL grammars:

- in SIMCs the verb consistently precedes (instead of follows) leftedge markers;

- in NSIMCs the verb consistently appears in second (instead of third) position; and

- OSCs are allowed.

This, in turn, provides preliminary evidence that the L2ers have reset both the SIP and the V2 parameter from their L1 (English) to their L2 (Afrikaans) values.

\footnotetext{
${ }^{13}$ See note 11 regarding which of the sentences formed by the subjects are included in the numbers in Table 2. Furthermore, as was mentioned in Section II, I assume (in keeping with Bobalijk and Thráinsson, 1998) that, in V2 languages, both SIMCs and NSIMCs are CPs and, therefore, that the position of the verb in Afrikaans SIMCs and NSIMCs is linked to the setting of the V2 parameter. However, as it is actually still being debated whether SIMCs are CPs or IPs in V2 languages (see, for example, Travis, 1984; 1991; Zwart, 1991; vs. Schwartz and Vikner, 1989; 1996), I counted only NSIMCs (i.e. constructions in which a topicalized object or adverb is in sentence-initial position) as V2- or V3-constructions.
} 
The results of the grammaticality judgement task are given in Table 3. The table shows accuracy (in percentage) in judging the various sentence types. For each sentence type, a one-way ANOVA was performed, comparing the L2ers' accuracy scores to those of the Afrikaans Controls. The L2ers performed like native speakers on all of the sentence types except the NSIMC(total)-category $(p=0.03)$. However, this significant difference between the two groups does not seem to be attributable to the L2ers preferring the ungrammatical V3-NSIMCs to the grammatical V2-NSIMCs. Of the 150 NSIMC pairs (i.e. 15 subjects $\times 10$ pairs) that the L2ers judged as a group, a total of 17 pairs were judged incorrectly. Of these 17 pairs, 11 were judged as 'both possible'. As was the case for the English Controls (see section a above), these errors are believed to be due to the additional 'both possible' instruction. ${ }^{14}$ Another 4 pairs were judged as 'both impossible'. All of these pairs involved a topicalized object. The L2ers might have transferred this dislike for topicalized objects from their L1 (as it was also found for the English Controls). The remaining 2 pairs that were judged incorrectly were judged as either 'only (a) is possible' or 'only (b) is possible'. Thus, the L2ers preferred the ungrammatical V3-order to the grammatical V2-order for only 2 of the 150 NSIMCpairs (a mere 1.3\%). Given the results of this error analysis, I propose that the significant difference between the L2ers and the Afrikaans Controls on the NSIMC(total)-category can effectively be disregarded. In other words, the L2ers performed like native speakers on all of the sentence types in the grammaticality judgement task, again suggesting that, in their IL grammars:

- in SIMCs the verb precedes left-edge markers;

- in NSIMCs the verb appears in second position; and

- OSCs and TECs are allowed.

These results, together with those of the sentence manipulation task, provide evidence that the L2ers have reset both the SIP and the V2 parameter from their L1 (English) to their L2 (Afrikaans) values.

\footnotetext{
${ }^{14}$ See Section V for a discussion of the possibility that these L2ers' IL grammars incorporate a
} V2/V3-optionality. 
84 The Split-IP parameter and the V2 parameter in L2 Afrikaans

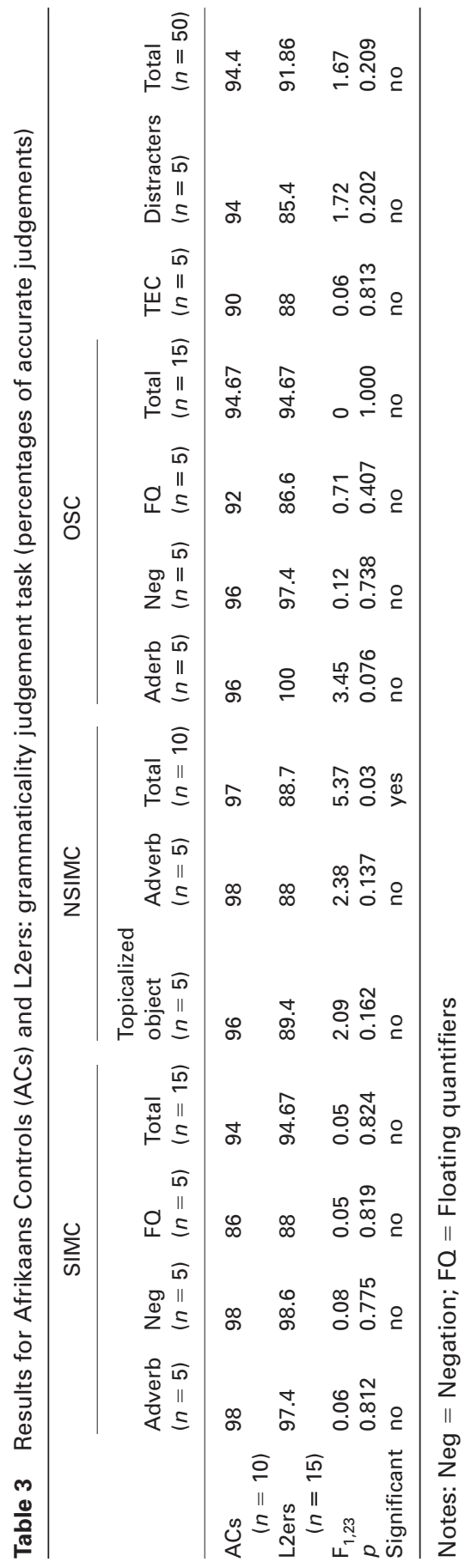


The results of the truth-value judgement task are given in Table 4, presented as percentage of accurate judgements (of 'true' or 'false'). A one-way ANOVA was performed on each of the subcategories, comparing the L2ers' accuracy scores to those of the Afrikaans Controls. As can be seen from the results in Table 4, there is a significant difference between the L2ers and the Afrikaans Controls in their total accuracy scores on the truth-value judgement task $(p<0.073)$. However, this difference is not due to the L2ers' judgements on the OS items $(p>0.05)$ but rather to their judgements on the no-OS items $(p<0.013) .{ }^{15}$ On the basis of these results, one might be tempted to conclude that the L2ers do not have knowledge of the semantic effect that is being tested here. However, note that the L2ers still perform far better than chance on the no-OS items (at 71\%); and that it is surprising that they have trouble with the no-OS items instead of the OS items, since it is the latter construction type that is not found in their L1. Keeping these facts in mind, I follow an argument presented by Grimshaw and Rosen (1990) and propose that one should not compare the L2ers' performance on the OS items with their performance on the no-OS items; rather, one should compare their 'true' responses to the OS items with their 'true' responses to the no-OS items. If the L2ers do not have knowledge of the property under investigation, they should treat the two sentence types (OS and no-OS) the same; if they consistently treat the OS items differently from the no-OS items, this suggests that they have knowledge of the relevant property.

Table 4 Results for Afrikaans Controls (ACs) and L2ers: truth-value judgement task (percentage of accurate judgements)

\begin{tabular}{lllll}
\hline & OS $(n=3)$ & No-OS $(n=3)$ & Distracters $(n=4)$ & Total $(n=10)$ \\
\hline ACs $(n=10)$ & 96.67 & 100 & 100 & 99 \\
L2ers $(n=15)$ & 93.33 & 71 & 96.75 & 88 \\
F $_{1,23}$ & 0.26 & 13.40 & 1.42 & 8.65 \\
$p$ & 0.6147 & 0.0013 & 0.2463 & 0.0073 \\
Significant & no & yes & no & yes \\
\hline
\end{tabular}

\footnotetext{
${ }^{15}$ Recall that all of the OS items are false, whereas all of the no-OS items are true (see note 12 for the rationale behind this decision). Therefore, a possibility that needs to be considered is whether the L2ers were biased towards answering 'false'. However, this does not seem to be the case: the L2ers answered $93.33 \%$ of the false items correctly and $82.67 \%$ of the true items. Nevertheless, a truth value judgement task that contains both true and false OS items and both true and false no-OS items has been designed and will be used in future experiments.
} 
Table 5 Results for Afrikaans Controls (ACs) and L2ers: percentages of 'true' responses on truth-value judgement task

\begin{tabular}{lll}
\hline & OS & No-OS \\
\hline ACs $(n=10)$ & $3.33 \%(1 / 30)$ & $100 \%(30 / 30)$ \\
L2ers $(n=15)$ & $(n=3$ items $\times 10$ subjects $)$ & $(n=3$ items $\times 10$ subjects $)$ \\
& $\begin{array}{l}\text { ( } n \text { ) } \\
(n=3 \text { items } \times 15 \text { subjects })\end{array}$ & $\begin{array}{l}71.11 \%(32 / 45) \\
(n=3 \text { items } \times 15 \text { subjects })\end{array}$ \\
\hline
\end{tabular}

Table 5 shows that the L2ers only responded 'true' to $6.67 \%$ of the OS items, whereas they responded 'true' to $71.11 \%$ of the no-OS items. Thus, although the L2ers performed worse on the no-OS items than on the OS items (Table 4), they clearly treated the OS items differently from the no-OS items (Table 5). Following Grimshaw and Rosen's argument, this means that the L2ers must have knowledge of the OS/noOS distinction, and that there must be some other reason why they are having trouble with the no-OS items on the truth-value judgement task in this study. I propose that this reason may be related to the fact that the test sentences all involved the negative element nie, and that the subjects were asked to respond 'true' or 'false' to each sentence. Consider again the no-OS and OS sentences in (21) and (22), repeated here as (24) and (25).

24) Sven het nie drie boeke gelees nie. (No-OS: neg $>$ \#DO)

Sven has not three books read final-NEG

'It is not true that Sven has read three books.'

25) Sven het drie boeke nie gelees nie. (OS: \#DO > NEG)

Sven has three books not read final-NEG

'There are three books that Sven hasn't read.'

The no-OS sentence in (24) is a negative statement: 'it is NOT the case that Sven has read three books': it negates the sentence Sven het drie boeke gelees 'Sven has read three books'. The OS sentence in (25), on the other hand, is an affirmative statement: 'it IS the case that there are three books that Sven hasn't read': it does not negate the sentence Sven het drie boeke gelees 'Sven has read three books' (or any other sentence, for that matter). ${ }^{16}$ This is characteristic of all of the test items in the truth-value judgement task: all of the no-OS items are negative statements and all of the OS items are affirmative statements. Assume, 
for the sake of this exposition, that the no-OS items make statements with the structure 'Not-X', whereas the OS items make statements with the structure ' $X$ '. In the case of the OS items (' $X$ '), answering 'true' or 'false' is straightforward: 'true' means ' $\mathrm{X}$ is true' and 'false' means ' $\mathrm{X}$ is false'. However, in the case of the no-OS items ('Not- $X$ '), the decision is not so straightforward: 'true' means 'Not- $\mathrm{X}$ is true', which in turn means ' $\mathrm{X}$ is false'; 'false' means 'Not- $\mathrm{X}$ is false', which in turn means ' $\mathrm{X}$ is true'. It is thus entirely plausible that the L2ers (like the Afrikaans Controls) have knowledge of the semantic distinction between OS and no-OS, but that the difference in processing difficulty between the OS items and the no-OS items led to a decrease in their performance on the no-OS items. Note that I am not proposing that no-OS constructions are inherently more difficult to process than OS constructions. Rather, my proposal is that, on this truth-value judgement task, the items involving no-OS are more difficult to process than the items involving OS, because the subjects are asked to respond with 'true' or 'false'. It is thus a property of the task itself and not of the structure of OS vs. no-OS constructions that leads to the difference in processing difficulty. It is, furthermore, reasonable to assume that this processing difficulty is more severe when one is judging a sentence in one's L2 than when one is judging a sentence in one's native language, which would account for the fact that the Afrikaans Controls do not perform significantly worse on the no-OS items than on the OS items.

Given all of the above-mentioned considerations, it would appear that the L2ers do have knowledge of one of the semantic effects (i.e. scope effects) of OS, a phenomenon that is not instantiated in their L1. As the semantic effect under consideration is a subtle effect (with the exception of one subject, not even the Afrikaans Controls were able to figure out what was being tested in the truth-value judgement task), and as this is not taught in Afrikaans-as-a-first-language or Afrikaans-as-asecond-language instruction, it seems plausible to assume that this knowledge must have been provided by UG. This, in turn, provides evidence for access to the relevant part(s) of UG in L2 acquisition. ${ }^{17}$ Admittedly, this is only preliminary evidence, as the problems with the 
above-mentioned task require attention (for example, more items need to be included: see footnote 15$)$.

\section{Discussion}

The study reported in this article investigated the question of whether or not English-speaking learners of Afrikaans are able to reset the SIP and the V2 parameter. The L2ers in this study performed like native speakers on all sentence types in the sentence manipulation task and the grammaticality judgement task, and the results of the truth-value judgement task indicate that the relevant semantic OS/no-OS distinction must be part of their IL grammars. The L2ers in this study thus have IL grammars which contain:

- a setting of the SIP different from that instantiated in their L1 grammar, namely $[+\mathrm{SIP}]$;

- a setting of the V2 parameter different from that instantiated in their L1 grammar, namely [+V2]; i.e. the V2-feature in C; and

- knowledge of one of the subtle semantic effects of a phenomenon that is not instantiated in their L1 grammar, namely OS.

The results of this study are, therefore, consistent with the Full Access hypothesis.

To conclude, I briefly consider some issues that arise with respect to the study reported here:

- whether there might be a V2/V3-optionality in the L2ers' IL grammars;

- whether the L2ers' knowledge of the semantic effects of OS really provide evidence for non-L1 UG-involvement; and

- whether the L2ers were only able to reset the relevant parameters because they were exposed to the L2 before the closure of a critical period.

a V2/V3-optionality in the L2ers' IL grammars: Recall that the only significant difference between the L2ers and the Afrikaans Controls on the grammaticality judgement task involved the NSIMC(total)-category (see Section IV and Table 3). On the basis of an analysis of the errors 
that the L2ers made in this category, it was argued that this significant difference can be disregarded, and that the results provide evidence that the L2ers have reset the V2 parameter to [+V2]. Specifically, 11 of their 17 errors are claimed to be due to the additional 'both possible' instruction. However, it might be argued that these errors instead indicate a V2/V3-optionality in the learners' IL grammars.

Such a V2/V3-optionality was reported by Robertson and Sorace (1999: 317) for two groups of German learners of English, who, they claim, 'retain a verb-second (V2) constraint [transferred from their L1 grammar; SC] in their interlanguage (IL) grammars until an advanced stage of development'. Robertson and Sorace offer a very interesting account for this residual V2 constraint, the predictions of which deserve to be pursued in future research. (The reader is referred to Robertson and Sorace's article for the details of their account.) Nevertheless, I do not believe that this V2/V3-optionality exists in the IL grammars of the L2ers investigated in the study reported here, for a number of reasons.

First, if there really is a V2/V3-optionality in the L2ers' IL grammars, one would expect them to form both V2- and V3-NSIMCs on an elicited production task. Consequently, their performance on the sentence manipulation task would be completely unexpected. Recall that only one L2er formed a single V3-NSIMC; the other 210 NSIMCs formed by the L2ers are all V2-constructions (see Table 2).

Second, the effect of the 'both possible' instruction is not just conveniently proposed to account for the fact that $65 \%$ of the errors made by the L2ers on the NSIMC-items involved 'both possible' responses. This effect is also evident in the errors made by the two control groups on the grammaticality judgement task. 'Both possible' responses account for $43 \%$ of the errors made by the Afrikaans Controls and $58 \%$ of the errors made by the English Controls.

Third, it should be noted that the difference between the Afrikaans Controls and the L2ers on the NSIMC-items becomes significant only when the results of the two subcategories - NSIMC-adverb and NSIMC-topicalized-object - are merged. There is no significant difference between the two groups on either of these categories separately.

Finally, the individual L2ers' scores on the NSIMC-category also indicated that they had reset the V2 parameter from [-V2] to [+V2]: of 
the 15 L2ers, four scored 10/10, seven scored 9/10, two scored 8/10 and two scored $7 / 10$.

$b$ The L2ers' knowledge of the semantic effects of OS: In Section IV, it is claimed that the results of the truth-value judgement task - i.e. that the L2ers have knowledge of the subtle semantic effects of OS (a phenomenon not instantiated in their L1) - provide evidence for access to the relevant parts of UG in L2 acquisition. The fact that the L2ers do worse on the no-OS items than on the OS items is accounted for in terms of a task effect.

However, one reviewer argues that 'there is no learnability challenge' that justifies positing UG-involvement in this case, since learners can transfer the relevant knowledge from their L1. He claims that the interpretive difference between the no-OS and the OS constructions in (21) and (22), repeated in (26) and (27) below, reduces to a universal scope effect that is identical to that found in English when the direct object is moved. His argument is based on the examples in (28) to (30) below.

26) Sven het nie drie boeke gelees nie. (No-OS: NEG $>$ \#DO)

Sven has not three books read final-NEG

'It is not true that Sven has read three books.'

27) Sven het drie boeke nie gelees nie. (OS: \#DO > NEG)

Sven has three books not read final-NEG

'There are three books that Sven hasn't read.'

28) Sven did not read three books.

29) Three books, Sven did not read.

30) Three books were not read by Sven.

The reviewer's argument is as follows: English (28) is the exact analogue of Afrikaans (26). In both cases, negation takes scope over the direct object, which is still in its VP-internal position, and, therefore, these sentences mean 'It is not the case that Sven has read three books'. Furthermore, English (29) and (30) are the exact analogues of Afrikaans (27). In all three cases, the direct object has been moved out of its VP-internal position into a position that takes scope over negation, and, therefore, these sentences mean 'There are three books that Sven hasn't read'. Consequently, the L2ers in this study can transfer knowledge of the scope effects of shifting the object, directly from their L1, English. 
I would like to propose that the matter is not as clear-cut as it would appear from the above argument. Note, first, that the Afrikaans sentences in (26) and (27) are unambiguous: (26) can only mean 'It is not the case that Sven has read three books', and (27) can only mean 'There are three books that Sven hasn't read'. This is not the case for the English sentences in (28) to (30): sentences like (28) are known to be ambiguous in that they can mean either 'It is not the case that Sven has read three books' or 'There are three books that Sven hasn't read' and, at least for some native speakers, sentences like (29) and (30) are ambiguous as well. Therefore, the semantic effects of shifting the object cannot be said to be identical in Afrikaans and English.

Furthermore, the semantic constraints on OS differ from language to language and seem to be especially weak in Afrikaans. In this language, OS seems to be optional in cases where it would not have an effect on scope relations. For this reason, all of the OS-items on the grammaticality judgement task are 'both possible' pairs, since both the no-OS sentence and its OS-counterpart are grammatical in these pairs. The L2er might incorrectly regard such OS/no-OS-optionality in the L2 input as additional evidence that no-OS and OS sentences such as those on the truth-value judgement task are ambiguous, arguing that, as OS and no-OS sentences are interchangeable in Afrikaans, one should be able to use both (26) and (27) to state that 'It is not the case that Sven has read three books', and both (26) and (27) to state that 'There are three books that Sven hasn't read'. Given these considerations, direct L1 transfer (as proposed by the reviewer) would predict that the L2ers should score closer to $50 \%$ on both the OS and the no-OS items on the truth-value judgement task.

I am not claiming that it is impossible that some kind of transfer from the L1 is involved in the knowledge that the L2ers exhibit in the truthvalue judgement task. I am simply proposing that direct L1 transfer alone cannot be responsible for the L2ers' knowledge of the semantic effects of OS in Afrikaans, and that, therefore, the L2ers' performance on the truthvalue judgement task does provide evidence for non-L1 UG involvement. Nevertheless, I recognize that this issue deserves further attention.

c The issue of a critical period for L2 acquisition: Since the L2ers who participated in this study were all exposed to Afrikaans from birth 
and started receiving Afrikaans instruction between the ages of 7 and 9, some proponents of the No Parameter Resetting hypothesis might object that these learners were all pre-critical period learners (i.e. child L2 learners rather than adult L2 learners) and that, therefore, it is not surprising that they seem to have managed to reset the SIP and the V2 parameter. The suggestion is that if these learners had started acquiring Afrikaans after the end of this critical period, as adults, they would not have been able to reset the parameters. Consequently, it would be interesting to compare child L2 learners of Afrikaans with adult L2 learners of Afrikaans.

With this goal in mind, I am now employing revised versions of the three tasks mentioned in this article to investigate the L2 acquisition of the SIP and the V2 parameter in Afrikaans by native speakers of English who were not born in South Africa and who started learning Afrikaans only when they started living (either temporarily or permanently) in South Africa as adults. This removes the critical period question, and the results, when compared with the results reported in this article, should provide some insight into the similarities and differences between child and adult L2 acquisition.

\section{References}

Alexiadou, A. and Anagnostopoulou, E. 1997: Postverbal subjects. Ms. Tilburg and MIT.

Ayoun, D. 1999: Verb movement in French L2 acquisition. Language and Cognition 2, 103-25.

Bobaljik, J.D. 1995: Morphosyntax: the syntax of verbal inflection. Unpublished PhD dissertation, MIT, Cambridge, MA.

Bobaljik, J.D. and Jonas, D. 1996: Subject positions and the roles of TP. Linguistic Inquiry 27. 195-236.

Bobaljik, J.D. and Thráinsson, H. 1998: Two heads aren't always better than one. Syntax 1, 37-71.

Chomsky, N. 1995: The minimalist program. MIT Press.

Clahsen, H. and Muysken, P. 1986: The availability of universal grammar to adult and child learners: a study of the acquisition of German word order. Second Language Research 2, 93-119.

- 1989: The UG paradox in L2 acquisition. Second Language Research 5, 1-29.

Crain, S. and Thornton, R. 1998: Investigations in universal grammar: a guide to experiments on the acquisition of syntax. MIT Press. 
Dekydtspotter, L., Sprouse, R.A. and Thyre, R. 1999: The interpretation of quantification at a distance in English-French interlanguage: domain specificity and second-language acquisition. Language Acquisition 8, 265-320.

Diesing, M. 1997: Yiddish VP order and the typology of object movement in Germanic. Natural Language and Linguistic Theory 15, 369-427.

Donaldson, B.C. 1993: A grammar of Afrikaans, Mouton de Gruyter.

Duffield, N. and White, L. 1999: Assessing L2 knowledge of Spanish clitic placement: converging methodologies. Second Language Research 15, 133-60.

Du Plessis, J., Solin, D., Travis, L. and White, L. 1987: UG or not UG, that is the question: a reply to Clahsen and Muysken. Second Language Research 3, 56-75.

Grimshaw, J. and Rosen, S.T. 1990: Knowledge and obedience: the developmental status of the binding theory. Linguistic Inquiry 21, 187-222.

Hawkins, R. and Yuet-hung Chan, C. 1997: The partial availability of universal grammar in second language acquisition: the 'failed functional features hypothesis'. Second Language Research 13, 187-226.

Hawkins, R., Towell, R. and Bazergui, N. 1993: Universal grammar and the acquisition of French verb movement by native speakers of English. Second Language Research 9, 189-233.

Iatridou, S. 1990: About Agr(P). Linguistic Inquiry 21, 551-77.

Mahajan, A. 1990: The A/A? distinction and movement theory. Unpublished $\mathrm{PhD}$ dissertation, MIT, Cambridge, MA.

Perlmutter, D. and Postal, P. 1984: The 1-Advancement exclusiveness law. In Perlmutten D. and Rosen, C., editors, Studies in Relational Grammar 2. University of Chicago Press, 81-125.

Pollock, J.-Y. 1989: Verb movement, universal grammar, and the structure of IP. Linguistic Inquiry 20, 365-24.

Rizzi, L. 1990: Relativized Minimality? MIT Press.

Robertson, D. and Sorace, A. 1999: Losing the V2 constraint. In Klein. E. and Martohardjono, G., editors, The development of second language grammars: a generative approach. John Benjamins, 317-61.

Schwartz, B.D. and Sprouse, R.A. 1994: Word order and nominative case in nonnative language acquisition: a longitudinal study of (L1 Turkish) German interlanguage. In Hoekstra, T. and Schwartz, B.D., editors, Language acquisition studies in generative grammar. John Benjamins, 317-68.

1996: L2 cognitive states and the full transfer/full access model. Second Language Research 12, 40-72.

Shwartz, B.D. and Vikner, S. 1989: All verb second clauses are CPs. Working Papers in Scandinavian Syntax 43, 27-49.

1996: The verb always leaves IP in V2 clauses. In Belletti, A. and Rizzi, L., editors, Parameters and functional heads: essays in comparative syntax. Oxford University Press, 11-62. 
Smith, N. and Tsimpli, I.-M. 1995: The mind of a savant: language learning abd modularity. Blackwell.

Thráinsson, H. 1996: On the (non-)universality of functional categories. In Werner, A., Epstein, S.D., Thráinsson, H. and Zwart, C.J.-W., editors, Minimal ideas. John Benjamins, 253-81.

2001: Object shift and scrambling. In Baltin, M. and Collins, C. editors, The handbook of contemporary syntactic theory. Blackwell 148-202.

Travis, L. 1984: Parameters and effects of word order variation. Unpublished $\mathrm{PhD}$ dissertation, MIT, Cambridge, MA.

— 1986: Parameters of word order and V2 phenomena. Paper presented at the Princeton Workshop on Comparative Syntax, Princeton, March 1986. (Subsequently published as Travis 1991.)

— 1991: Parameters of phrase structure and verb-second phenomena. In Freidin, R., editor, Principles and parameters in comparative grammar. MIT Press, 339-64.

Tsimpli, I.-M. and Smith, N. 1991: Second language learning: evidence from a polyglot savant. UCL Working Papers in Linguistics 3, 171-84.

Vainikka, A. and Young-Scholten, M. 1994: Direct access to X'-theory: evidence from Korean and Turkish adults learning German. In Hoekstra, T. and Schwartz, B.D., editors, Language acquisition studies in generative grammar. John Benjamins, 265-316.

— 1996: Gradual development of L2 phrase structure. Second Language Research 12, 7-39.

White, L. 1989: Universal grammar and second language acquisition. John Benjamins.

1991: Adverb placement in second language acquisition: some effects of positive and negative evidence in the classroom. Second Language Research 7, 133-61.

1996: Clitics in L2 French. In Clahsen, H., editor, Generative perspectives on language acquisition. John Benjamins, 335-68.

2003: Second language acquisition and universal grammar. Cambridge University Press.

Yuan, B. 2001: The status of thematic verbs in the second language acquisition of Chinese: against inevitability of thematic-verb-raising in second language acquisition. Second Language Research 17, 248-72.

Zwart, C.J.-W. 1991: Clitics in Dutch: evidence for the position of Infl. Groninger Arbeiten zur Germanistischen Linguistik 33, 71-92. 